Savunma Bilimleri Dergisi

The Journal of Defense Sciences

Kasim/Nov 2018, Cilt/Volume 17, Say1/Issue 2.

ISSN (Bas1l1) : 1303-6831 ISSN (Online): 2148-1776

\title{
Farklı Uygulamaların Akademik Başarı Bağlamında Çoklu Karşılaştırılması
}

\author{
Veli BATDI* ve Özgür ANIL**
}

$\ddot{O} z$

Bu araştırmanın amacı farkl uygulamaların akademik başarıyı ne düzeyde etkilediğini ortaya çıkarmaktır. Bu bağlamda farklı uygulamaların fen bilgisi ögrretimindeki kullanımına ilişkin meta-analiz; akıllı telefon kullanımının fen bilgisi ögretmen adaylarının akademik başarısına etkisine ilişkin deneysel uygulama ile tematik analize başvurulmuştur. Meta-analiz kapsamında farklı veri tabanları taranarak dâhil edilme ölçütlerine göre 20 çalışma analize dâhil edilmiştir. Veriler CMA ve MetaWin programlartyla analiz edilmiştir. Deneysel uygulama amactyla 2016-2017 akademik yllında Kilis 7 Aralık Üniversitesi fen bilgisi öğretmenliği 3. Sinıf ögrrencileri arasından seçilen 35 ögrenciye akıllı telefonla öğretim să̆lanmış ve hazırlanan akademik başarı testinin ön test ve son test uygulaması yapılmıştır. Veriler SPSS programıla analiz edilmiştir. Tematik analiz kapsamında maksimum çeşitliliğe göre seçilen 21 ögrenciye görüşme formu uygulanarak veriler Maxqda11 programıyla içerik analizine uygun çözümlenmiştir. Araştırmanın her ü̧ boyutunda ulaşılan bulgular farklı uygulamaların ve akıllı telefonların akademik başarıya etkisinin pozitif ve anlamlı olduğunu göstermiştir. Buna ilişskin araştırma sonunda çeşitli öneriler sunulmuştur.

Anahtar Kelimeler: Farklı Uygulamalar, Akıllı Telefon, Akademik Başarı, Çoklu Analiz, Fen Bilgisi Ögretmen Adayları.

* Doç.Dr., Kilis 7 Aralık Üniversitesi, M. R. Eğitim Fakültesi, veb_27@hotmail.com

** Dr., Millı̂ Savunma Üniversitesi, Kara Harp Okulu, Temel Bilimler Bölüm Başkanlığı, Fizik Öğretim Eleman1, ozguranil@ mynet.com 


\title{
A Multi-Comparative Analysis of Different Applications in Academic Achievement Context
}

\begin{abstract}
The aim of this research is to determine the efficiency of different applications on academic achievement. In this context, a-meta-analysis of the use of different methods and techniques in science teaching; an experimental application and a thematic analysis of the effect of using smartphone on Science Teacher candidates' academic achievement were applied. Within meta-analysis, 20 different studies were included in the analysis according to their inclusion criteria following the search of different databases. Data were analysed through CMA and MetaWin programs. For the purpose of experimental application, 35 students selected from 3rd grade students of Kilis 7 Arallk University Department of Science Teacher Training during 2016 and 2017 academic years were provided with smart phone and the prepared academic achievement test was applied as in pre and post-tests. The data were analysed by SPSS program. In the thematic analysis, 21 students' interview forms selected according to the maximum variation sampling were applied and the data were analysed according to the content analysis through Maxqda-11 program. Findings in all three dimensions of the research showed that different applications and smartphones were positive and significant on the effect of academic achievement. Various suggestions were presented at the end of the research.
\end{abstract}

Keywords: Different Applications, Smartphone, Academic Achievement, Multi Analysis, Science Teacher Candidates.

Giriş

Fen bilimleri; doğayı ve doğal olaylarını sistemli bir şekilde inceleme, henüz gözlenmemiş olayları kestirme gayretleri olarak tanımlanabilir. Fen bilimlerinin içeriğinin; olgular, kavramlar, ilkeler ve genellemeler, kuramlar ve doğa kanunlarını kapsadığı görülmektedir (Kaptan ve Korkmaz, 2001). Fen bilimlerinin öğrenenlere etkili bir biçimde aktarılması için öğretmen yetiştirme sürecinin kapsamlı bir biçimde ele alınması gerekir. Bu bağlamda fen bilgisi 
öğretmen adayının; akademik başarısı üst seviyede, alan bilgisine sahip, disiplinler aras1 ilişkileri çok iyi izleyen, araştırmayı, incelemeyi ve eleştirel düşünceyi öğreten ve öğrencilerde iç uyarım geliştiren bir öğretmen olarak yetişebilmesi hedeflenmelidir (Meriç ve Tezcan, 2016).

Fen bilgisi öğretmen adaylarının yetiştirilmesi aşamasında başat faktörlerden biri olan "akademik başarının" artırılmasına yönelik birçok çalışmaya rastlanmıştır (Alouf ve Bentley, 2003; Burke, Hand, Poock ve Greenbowe, 2005; Gardner, 2008; Günay, 2008; Hohenshell ve Hand, 2006; Kearney, 2004; Klangmanee ve Sumranwanich, 2009; Kleregis ve Hurren, 2011; Menevşe, 2012; Turpin ve Cage, 2004; Wise ve Bluhm, 2008; Yip, 2001). Bu çalışmalardan birinde fen bilgisi öğretmen adaylarına yönelik "kavram haritaları" ve "kavram değişim metinleri" ile yapılandırılan öğretimin, geleneksel öğretime göre daha başarılı olduğu ve öğretmen adaylarının akademik başarısını olumlu yönde etkilediği sonucuna varılmıştır (Yip, 2001). "Tahmin et - gözle - açıkla" stratejisine dayalı laboratuvar uygulamalarına yönelik çalışmalarda da öğretmen adaylarının diğer öğretmen adayları ile etkili bir iletişime geçtikleri, grup halinde çalışmaya istekli oldukları ve akademik başarılarının artı̆̆ı gözlemlenmiştir (Kearney, 2004; Klangmanee ve Sumranwanich, 2009). Bilgisayar destekli öğretim uygulamalarının geleneksel öğretim uygulamaları ile karşılaştırıldığı araştırmalarda; bilgisayar destekli öğretimin öğrenci adaylarının bilgi ve kavrama seviyelerini yükselttiği ve akademik başarılarını arttırdığ1 sonucuna varılmıştır (Günay, 2008).

Probleme dayalı öğrenmenin uygulandığı çalışmaların sonuçları incelendiğinde ise; fen bilgisi öğretmen adaylarının problem çözme beceri algılarının ve akademik başarılarının arttı̆̆ 1 gözlemlenmiştir (Kleregis ve Hurren, 2011). Öğretim sürecini 5E öğrenme modeli çerçevesinde yapılandıran çalışmalarda; öğretmen adaylarının akademik başarılarının yükseldiği ve derse olan tutumlarının olumlu anlamda değiştiği görülmüştür (Wise ve Bluhm, 2008). Proje tabanlı öğrenmenin temele alındığı bir çalışmada ise öğretim sürecinin öğrenci adaylarının bilimsel süreç becerilerinin gelişimine katkısı olduğu ve akademik başarı seviyesini yükselttiği sonucuna ulaşılmıştır (Turpin ve Cage, 2004).

Yapılandırmacı kurama dayalı "araştırma-soruşturma tabanlı öğretimin" uygulandığı çalışmalara ilişkin sonuçlar incelendiğinde; öğretim sürecinin sonunda fen bilgisi öğretmen adaylarının problem çözme becerilerinin geliştiği, fen 
öğretimine yönelik öz-yeterlik inanç düzeylerinin ve akademik başarı seviyelerinin arttığ gözlenmiştir (Alouf ve Bentley, 2003). Diğer yandan bireysel gelişim dosyası uygulamasının kullanıldığı öğretim süreçlerinin incelendiği araştırmalarda; uygulama sonunda akademik başarının ve hatırlama düzeyinin önemli düzeyde artış gösterdiği bulgulanmıştır (Menevşe, 2012; Gardner, 2008). Yaparak yazarak bilim öğrenme yaklaşımın uygulandığı öğretim süreçlerinin sonunda, öğretmen adaylarının akademik başarılarının artış gösterdiği ve bilimsel süreç becerilerinin geliştiği gözlemlenmiştir (Burke, Hand, Poock ve Greenbowe, 2005; Hohenshell ve Hand, 2006).

İnternet tabanlı telefon uygulamalarının akademik başarıya etkisini inceleyen araştırmalar incelendiğinde ise bilgi toplama ve paylaşma sürecine imkân veren uygulamaların öğrencilerin araştırma, sorgulama ve problem çözme becerilerini kullanmalarını ve geliştirmelerini desteklediği, üst düzey düşünme becerilerine katkı sağladığ 1 ve akademik başarıya olumlu etkisi olduğu bulgulanmıştır (Hung ve Yuen; 2010; Junco, 2012; Murray, 2008; Öztürk ve Tetik, 2015). İnternet üzerinden birden fazla katılımcının etkileşmesine imkân veren öğretim amaçlı uygulamaların öğrencilerin derse olan ilgilerini artırdığı, bağımsız öğrenmeyi destekleyerek sorumluluk duygusunu geliştirdiği, öğrencilerin öğrenme sürecini desteklediği, bilgi okuryazarlığına katkıda bulunduğu, öğretim süreçlerini geliştirerek derslerin organize edilmesine katkı sağladığı, işbirlikçi öğrenme aktivitelerini teşvik ettiği, öğretmenler ve öğrenciler arasında daha güçlü bir iletişim ortamı yarattığ1 görülmektedir (Augar, Raitman ve Zhou, 2004; Backer, 2010; Kolari, Finin ve Joshi, 2006; Lam, 2012; Malita, 2011; Minocha ve Roberts, 2008; Schwartz, Clark, Cossarin ve Rudolph, 2004).

Öğretim içeriğinin farklı biçimlerde sunulabilmesine yardımcı olan bu uygulamaların (probleme dayalı öğrenme, çoklu zekâ kuramı temelli öğretim, bağlam temelli yaklaşım, tahmin et - gözle - açıkla yöntemi, araştırma-soruşturma tabanlı öğretim, kavram haritaları, laboratuvar uygulamaları, bilgisayar destekli öğretim, proje tabanlı öğrenme, internet tabanlı telefon uygulamaları vb.); akademik başarıya ve bilginin kalıcılığına olumlu katkı sağladığı, bilimsel süreç ve problem çözme becerilerinin gelişimine yardımcı olduğu ve derse olan tutumu olumlu yönde etkilediği ilgili araştırma sonuçlarından anlaşılmaktadır. 


\section{Araștırmanın Amacı ve Önemi}

Meta-analiz, belli bir alanda yapılmış birçok çalışmanın sonuçlarının ortalama bir etki değerine ulaşmak amaciyla birleştirilmesini ve elde edilen bulgularının istatistiksel olarak analiz edilebilmesini amaçlayan nicel bir yöntemdir (Witte ve Allen, 2000). Mevcut çalışma ise farklı öğretim yöntem ve tekniklerinin akademik başarı boyutunda ne derece etkin olduğunu ortaya koyabilmeyi hedeflemektedir. $\mathrm{Bu}$ kapsamda, öğretim ortamında farklı öğretim yöntem ve tekniklerinin kullanıldığı çeşitli türdeki (makale, tez) araştırmalar belli ölçütler dikkate alınarak incelenmiş ve bu doğrultuda nitelikli bir çalışma sunulması amaçlanmıştır. Meta-analiz kapsamında, fen bilgisi öğretmen adaylarına yönelik olarak gerçekleştirilmiş ulusal ve uluslararası alanda birçok çalışma incelendiğinden, adayların akademik başarı durumlarına ilişkin daha kapsamlı ve genel sonuçlara ulaşılacağı düşünülmektedir. İlgili alanyazın tarandığında, teknolojinin kullanımına ilişkin sosyal ağlarda bireysel etkinliklerin eğitsel analizini içeren (Kwon ve Wen; 2010), sosyal ağların öğretim sürecinde nasıl kullanılabileceğine odaklanan (Ekici ve Kıyıcı, 2012), sosyal ağların öğrenme üzerindeki etkisini irdeleyen (Atıcı ve Yıldırım; 2010; İşman ve Albayrak, 2014; Lim, 2010; Sánchez, Cortijo ve Javed, 2014; Selwyn, 2009) birçok çalışma mevcuttur. Ancak internet tabanlı akıllı telefon uygulamalarının akademik başarıya etkisi ile ilgili çalışmalar sınırlı sayıdadır (Hung ve Yuen, 2010; Junco, 2012; Murray, 2008; Öztürk ve Tetik, 2015). Alanyazında teknoloji odaklı mevcut araştırmadan farklı çalışmalara rastlanmıştır. $\mathrm{Bu}$ bağlamda akıllı telefonların alandaki eksikliğin doldurulmasına katkıda bulunduğu, eğitimdeki kullanımı konusunda ulaşılan sonuçları paylaşmak üzere bu araştırmanın yapılmasının düşünüldüğü ve ilgili araştırma sonuçlarının gelecekteki diğer çalışmalara 1 şık tutmasının beklendiği belirtilebilir.

İnternet tabanlı akıllı telefon uygulamalarının hem Türkiye'de hem de dünyada giderek arttığı dikkate alındığında söz konusu uygulamalara ilişkin bir örnek durumun incelenmesi ve akademik başarı durumlarının ortaya çıkartılmaya çalışılması önemli görülmektedir. Akıllı telefonların öğretime entegre edilme sürecinin derinlemesine analiz edildiği çalışmaların, eğiticilere fikir verebileceği düşünülmektedir. Yukarıdaki belirlemeler 1şığında bu araştırmanın amacı, fen 
bilgisi öğretmen adaylarının görüşleri açısından akıllı telefon uygulamalarının akademik başarı üzerindeki etkililiğini sorgulamaktır. Yapılan çalışmanın, alanyazına katkı sağlayarak araştırmacıların gelecekte yapacakları çalışmalara yeni ve farklı bir perspektiften bakmalarına imkân tanıyacak önemde olduğu söylenebilir. Bu bağlamda araştırmanın daha geniş yaygın etkiye sahip olmasını sağlayabilecek çoklu analiz yaklaşımı kapsamında, üç temel boyuta dayalı araştırma yapılması amaçlanmıştır:

- Farklı uygulamaların, öğretmen adaylarının akademik başarılarına ilişkin etki büyüklüğü değeri nedir?

- Öğretmen adaylarının, öntest-sontest akademik başarı puanları arasında anlamlı bir fark var mıdır?

- Öğretmen adaylarının görüşleri açısından akıllı telefon uygulamalarının akademik başarı üzerindeki etkililiği nedir?

\section{Yöntem}

\section{Araștırmanın Modeli}

$\mathrm{Bu}$ araştırmada, farklı uygulamalar olarak nitelendirdiğimiz bazı öğretim yaklaşımlarının fen bilgisi öğretimindeki kullanımının akademik başarı bağlamındaki etkililiğini değerlendirmek üzere meta-analiz, deneysel uygulama ve tematik analize başvurulmuştur. Hem nicel hem de nitel boyutta yürütülen bu çalışmanın karma yöntem kullanmasının amacı, daha kapsamlı ve geniş çaplı veriler elde ederek daha genel sonuçlara ve yargılara varmaktır. Eşzamanlı karma yöntem türüne uygun bu araştırmada nicel ve nitel verilerin sonuçları mevcut olan bir çalışma içinde birbirini tamamlama destekleme ve birbiriyle tutarlılık sağlama durumuna imkân vermektedir (Creswell, Plano Clark, Gutmann ve Hanson, 2003). Fen bilgisi dersinde yürütülen çalışmaların etki büyüklüğünü hesaplamak amacıyla meta-analitik yöntemden yararlanılmıştır. Meta-analiz yönteminde bireysel olarak yapılmış birbirinden ayrı olan çalışma sonuçlarının genel bir karara varmak amaciyla bir araya getirilmesi söz konusudur (Glass, 1976, s. 3). Diğer bir ifadeyle, bir araştırmada genel kapsamlı bir sonuca ulaşmak amacıyla alanyazında taranan ilgili çalışmaların sonuçlarını birleştirmek, değerlendirmek ve sentezlemek için 
kullanılan sistematik bir yaklaşım olarak açıklanabilir (Stroup vd., 2000). Metaanaliz sonucu litaratürde yapılan çalışmalarda farklı uygulamalar kapsamında birçok yaklaşımın akademik başarıya etkisini inceleyen çalışmalara ulaşıldığ 1 görülmüsşür. Ancak akıllı telefon kullanımının akademik başarıya etkisine ilişkin alanyazında pek fazla çalışmaya ulaşmamıştır. $\mathrm{Bu}$ durumda akıllı telefon kullanımının akademik başarıya etkisini incelemek üzere fen bilgisi öğretmen adayları ile işlenen derslerde akıllı telefon uygulaması yapılmıştır. Bu boyut ise araştırmanın deneysel yönünün oluşturmaktadır. Araştırma kapsamında son olarak araştırmanın meta-analiz ve deneysel uygulama sonuçlarını desteklemesi amacıyla görüş başvurusunda bulunulmuştur. Bu noktada, araştırmalarda sorunların ortaya çıkmasını sağlayan ve ilgili sorunların çözümüne ilişkin veriler toplanmasını kapsayan eylem araştırması desenine (Yıldırım ve Şimşek, 2008) uygun davranılmıştır.

\section{Analize Dahil Edilen Çalışmalar/Çalışma Grubu}

Meta-analiz kapsamında, fen bilgisi öğretmen adaylarının yetiştirilmesi sürecinde kullanılan öğretim yöntem ve teknikleri ile ilgili YÖK Ulusal Tez Merkezi, Google Scholar veri tabanlarındaki 2008-2017 yılları arasında yapılmış makaleler ve ulaşım izni verilen tezler incelenmiştir. Konu ile ilgili olarak 172 adet çalışmaya ulaşılmıştır. Ulaşılan çalışmaların; 2008-2017 yılları arasında yapılmış olması, etki büyüklüğü değerine ulaşmayı sağlayacak örneklem büyüklüğü (n), aritmetik ortalama (X) ve standart sapma (ss) gibi istatiksel değerleri içermesi ve ön test-son test kontrol grup modeli kullanması şeklindeki dâhil edilme ölçütlerine uygunluğu incelenmiştir. Sonuç olarak bu ölçütlere uygun 20 adet çalışma araştırma kapsamına alınmıştır. Ayrıca çalışmalardan bazıları deneysel nitelik taşımadığı için araştırma kapsamına dâhil edilmemiştir.

Deneysel boyutta, 2016-2017 akademik yılında Kilis 7 Aralık Üniversitesi Eğitim Fakültesi Fen Bilgisi Öğretmenliği 3. sınıf öğrencileri arasından seçilen 35 öğrenci çalışma grubunu oluşturmuştur. Son olarak nitel boyutta, çalışma grubu kapsamında yer alan 35 öğrenciden akademik başarı testindeki puanları dikkate alınarak maksimum çeşitliliğe uygun şekilde 21 öğrenci ( 7 iyi, 7 orta, 7 alt akademik düzeyde) seçilmiştir. Farklı gruplardaki durumları yansıtmak ve farklı 
yönlerini ortaya çıkarmak amacıyla maksimum çeşitlilik kullanımı sağlanmıştır (Patton, 2014).

\section{Veri Toplama Araçları ve Analiz Süreci}

Meta-analiz bağlamında ulaşılan veriler CMA ve MetaWin programlarıyla analiz edilmiş ve yorumlarda Cohen'in (2002) düzey sınıflaması dikkate alınmıştır. Ayrıca kodlayıcılar arası güvenirlik hesaplaması yapılarak [görüş birliği / (görüş birliği + görüş ayrıllı̆̆) x 100] (Miles ve Huberman, 1994) sonucun \%100 olduğu görülmüştür. Diğer taraftan meta-analiz için yayım yanlılığını ortadan kaldırma veya en aza indirmek amaciyla hesaplanan hata koruma sayıs1 (Rosenthal, 1979) (fail-safe number) 8335.7 olarak bulunmuştur.

Araştırmanın deneysel uygulama boyutunda, akıllı telefonların Ölçme ve Değerlendirme dersinde 4 hafta boyunca kullanımı sağlanmıştır. Uygulama öncesi ve sonrası uygulanan öntest ve sontest verilerine ulaşmak amacıyla akademik başarı testi hazırlanmıştır. 24 sorudan oluşan ve geçerlik ve güvenirliği TAP programıyla sağlanan testin, dönem başında ve sonunda uygulaması yapılmıştır. (Ek A). Testin ortalama güçlüğü .571, KR-20 güvenirlik kat sayısı ise .91 olarak hesaplanmıştır. Ulaşılan verilerin analizi SPSS-18 programıyla gerçekleştirilmiştir. Diğer yandan katılımcılardan görüş almak için araştırmacılar ve uzman görüşlerinin doğrultusunda yarı-yapılandırılmış bir görüşme formu hazırlanmıştır (Ek B). Bu formdan elde edilen görüşler iki kodlayıcı tarafından ayrı ayrı incelenerek ortak tema ve kodlara gidilmiştir. $\mathrm{Bu}$ aşamada iki kodlayıcı güvenirliğini sağlamak üzere Cohen Kappa uyum değerleri hesaplanmış (Viera ve Garrett, 2005), uyumun .803 ile .819 değer aralığında ve iyi/çok iyi düzeyde olduğu anlaşılmıştır. İlgili kodların uygun temalar altında gruplanması sağlandıktan sonra modelleştirmeler yapılmıştır. Ayrıca verilerin çözümü Maxqda-11 programıla sağlanmıştır. Çalışmanın nitel bulgularına yer verilirken katılımcılardan alınan görüşlere doğrudan atıflar yapılmıştır. Yapılan atıflar italik vurguyla belirtilirken atıfların kimden alıntılandığı ise parantez içerisinde katılımcılara verilen kodlarla gösterilmiştir (örn: E-33: 33 nolu erkek katılımc1 veya $\mathrm{K}-10$ : 10 nolu kadın katılımcı). Yapılan doğrudan alıntıların araştırmanın güvenirliğine katkı sağladığı bilinmektedir (LeCompte ve Goetz, 1982). 


\section{İşlem}

Araştırmanın deneysel uygulama boyutunda, 2016-2017 akademik yılında Kilis 7 Aralık Üniversitesi Eğitim Fakültesi Fen Bilgisi Öğretmenliği 3. sınıf öğretmen adaylarıyla Ölçme ve Değerlendirme dersi "Ölçümlerin Güvenirliği ve Standart Hata" "Ölçümlerin Geçerliği", "Sınav Türleri ve Soru Yazımı", ve "Yazılı ve Sözlü Yoklamalar" ünite konuları çalışılmıştır. Uygulamaya başlamadan önce öğretmen adaylarının akademik başarı durumlarını belirlemek üzere araştırmacılar tarafından Ölçme ve Değerlendirme dersi kapsamında, yukarda belirtilen ünite başlıklarını içeren sorular hazırlanarak başarı testi oluşturulmuştur. İlgili başarı testi akıllı telefon kullanımı öncesi uygulanarak öntest puanlarına erişilmiştir. Ardından uygulamanın sistemli yürütülebilmesi için gerekli ön hazırlıklar yapılmıştır. Projeksiyon cihazına bağlanma ve içeriği yansıtma sorunları yaşanmaması için öğretmen adayı sunum öncesi prova yapmış ve gerekli hazırlıklarını tamamlamıştır. Öğretmen adaylarının öncelikle telefonlarına EZCast programını yüklemeleri sağlanmıştır. Akıllı telefonlara yüklenen bu program aracılığıyla, öğretmen adaylarının ilgili konu başlıklarına ilişkin hazırladıkları slaytları yansıtarak sunum yapmaları sağlanmıştır. Sunum esnasında gerekli görüldüğünde, ekstra bilgi sorgulaması ve araştırılması da yapılarak detaylı öğrenme imkânı sunulmuştur. 4 üniteye ilişkin hazırlanan konuların slayt sunumu böylece EZCast ile projeksiyona yansıtılarak gerçekleştirilmiştir. Sunum sırasında duraklamalar yapılarak konuyla ilgili sunucuya sorular yöneltilmiş ve cevaplar tartı̧̧ma ortamına açılarak öğretmen adaylarının katılımları sağlanmıştır. Sunumlar grupla hazırlandığı için bir noktada daha detaylı bilgi ve açıklama yapmak isteyen diğer bir grup üyesi sunuma kendi telefonuyla bağlanarak aktarmak istediği içeriği sunabilmiştir. 4 ünitenin içeriği bu şekilde 4 hafta boyunca akıllı telefonlarla işlenmiştir. 4 haftanın sonunda, aynı başarı testi gruba tekrar uygulanarak sontest puanlarına da erişilmiştir.

\section{Bulgu ve Yorumlar}

$\mathrm{Bu}$ araştırmada farklı uygulamaların fen bilgisi öğretmen adaylarının akademik başarıları üzerindeki etkisi meta-analitik, deneysel ve tematik boyutları içeren çoklu analiz kapsamında incelenerek belirlenmeye çalışılmıştır. $\mathrm{Bu}$ 
bağlamda, meta-analitik incelemeler yapılırken, farklı uygulamaları konu edinen analiz dâhilindeki tüm çalışmaların genel etki düzeyleri ile bu çalışmaların ayrı ayrı etki düzeyi büyüklükleri moderatör analizi şeklinde tablolarda sunulmuştur (Tablo 1 ve Tablo 2).

Tablo 1: Meta Analize Dâhil Edilen Çalışmaların Etki Modellerine Göre Homojen Dağılım Değeri, Ortalama Etki Büyüklüğü ve Güven Aralıkları Tablosu

\begin{tabular}{|c|c|c|c|c|c|c|c|c|}
\hline \multirow{2}{*}{ Model Türü } & \multirow{2}{*}{$\mathrm{n}$} & \multirow{2}{*}{$\mathrm{Z}$} & \multirow{2}{*}{$\mathrm{p}$} & \multirow{2}{*}{ Q } & \multirow{2}{*}{ E.B } & \multirow{2}{*}{ S.E } & \multicolumn{2}{|c|}{$\begin{array}{c}\text { \% } 95 \text { Güven } \\
\text { Aralığ } 1\end{array}$} \\
\hline & & & & & & & $\begin{array}{c}\text { Alt } \\
\text { Sinırı }\end{array}$ & $\begin{array}{l}\text { Üst } \\
\text { Sinırı }\end{array}$ \\
\hline $\begin{array}{l}\text { Sabit } \\
\text { Etkiler } \\
\text { Modeli }\end{array}$ & 20 & 19.082 & 0.000 & 121.930 & 1.082 & 0.057 & 0.971 & 1.194 \\
\hline $\begin{array}{l}\text { Rastgele } \\
\text { Etkiler } \\
\text { Modeli }\end{array}$ & 20 & 8.172 & 0.000 & 21.152 & 1.189 & 0.145 & 0.904 & 1.474 \\
\hline
\end{tabular}

Tablo 1, meta-analiz kapsamında bulunan farklı uygulamalar konusundaki çalışmaların $(n=20)$ genel etki büyüklüğünü $(E S=1.189)$ vermektedir. $Q$ değerine bakıldığında etki büyüklüğünün heterojen yapıya sahip olduğu anlaşılmaktadır $(\mathrm{Q}=121.930, \mathrm{sd}=19, \mathrm{p}<.05)$. Diğer bir anlatımla $\mathrm{Q}$ istatistik değeri $\chi 2$ dağılımı kritik değerini aştı̆g 1 için homojenlik Sabit Etkiler Modelinde (SEM) reddedilerek Rastgele Etkiler Modelinde (REM) kabul görmüştür. Bu durum, analizlerdeki etki büyüklükleri değişiminin örneklem hatasından dolayı olan bir değişimden bekleneceğinden daha büyük olması gerekçesiyle (Borenstein, Hedges, Higgins ve Rothstein, 2009) hesaplamaların REM'de yapılmasına neden olmuştur.

Tabloda sunulan genel etki büyüklüğü değeri (1.189) Cohen'in (1992) sınıflamasına göre geniş düzeyde bulunmaktadır. Bu durum farklı uygulamaların fen bilgisi öğretmen adaylarının akademik başarıları üzerinde olumlu ve anlamlı etkiye sahip olduğunu göstermektedir. Tablo 2'de ise araştırmanın içerdiği farklı 
uygulamalar (çalışmalarda kullanılan yaklaşımlar) açısından analiz dâhilindeki çalışmaların etki büyüklükleri incelenmiştir.

Tablo 2: Çalışmaların Farklı Uygulamalar Açısından Etki Büyüklükleri

\begin{tabular}{|c|c|c|c|c|c|}
\hline \multirow{2}{*}{$\begin{array}{l}\text { Farklı } \\
\text { Uygulamala } \\
\text { r }\end{array}$} & \multirow{2}{*}{$\mathrm{N}$} & \multirow{2}{*}{$\begin{array}{l}\text { Ortalama } \\
\text { Etki } \\
\text { Büyüklüğğu } \\
\text { (EB) }\end{array}$} & \multicolumn{2}{|c|}{$\begin{array}{c}\text { Etki Büyüklüğü İçin \% } 95 \\
\text { Güven Aralığ1 }\end{array}$} & \multirow{2}{*}{$\begin{array}{l}\text { E.B. } \\
\text { Düzeyi }\end{array}$} \\
\hline & & & Alt Sinırı & Üst Sinırı & \\
\hline BİLG. & 8 & 1.195 & 0.717 & 1.672 & Geniş \\
\hline İÖY & 3 & 0.794 & -0.205 & 1.793 & Orta \\
\hline PDÖ & 3 & 1.666 & 0.564 & 2.767 & Geniş \\
\hline TGA & 3 & 1.273 & 0.999 & 1.546 & Geniş \\
\hline YAP. & 3 & 1.022 & 0.429 & 1.615 & Geniş \\
\hline Toplam & 20 & 1.219 & 1.008 & 1.430 & Geniş \\
\hline
\end{tabular}

Tablo 2'de analiz kapsamındaki Bilgisayar Destekli Öğretim (BİLG.), İşbirlikli Öğrenme Yöntemi (İ̈Y), Probleme Dayalı Öğrenme (PDÖ), “Tahmin Et-Gözle-Açıkla" (TGA) ve Yapılandırmacılık (YAP) yaklaşımlarına ilişkin analize dâhil edilen bütün çalışmaların etki büyüklükleri sunulmuştur.

Tablodaki sayısal veriler incelendiğinde, gruplar arası homojenlik testi $\mathrm{Q}_{\mathrm{B}}=1.909$ olarak hesaplanmıştır. $\chi 2$ tablosunda $\% 95$ anlamlılık düzeyinde, 4 serbestlik derecesi ile kritik değer 9.488 biçiminde hesaplanmıştır $\left(\chi 2_{(0.95)}=9.488\right)$. $\mathrm{Q}_{\mathrm{B}}$ değerinin $\left(\mathrm{Q}_{\mathrm{B}}=1.909\right) \chi 2$ dağ1lımındaki kritik değerden $\left(\chi_{(0.95)}=9.488\right)$ küçük olması dağılımın homojen yapıda olduğu anlamına gelmektedir. Bu durumda homojenlik SEM'de kabul edilmiştir. Buna göre farklı uygulamaların akademik başarı üzerindeki etkililiğinin uygulama türüne göre anlamlı düzeyde farklılaşmadığı bulunmuştur ( $\mathrm{Z}=11.323 ; \mathrm{p}=0.753)$. Ayrıca Tablo 2'de farklı uygulamalar olarak sıralanan yaklaşımlar arasında etki büyüklüğü düzeyi en yüksek olanın PDÖ; en düşük olanın ise İÖY olduğu görülmektedir.

Araştırmada meta-analitik boyutta kapsama alınan çalışmaların etki büyüklügünün normal dağılıma uygunluğu ise Şekil 1'de sunulan Normal Quantile 
Plot ile gösterilmiştir. Şekil 1'de çalışmaların analize uygunluğu ile ilgili güvenirlik aralığ1 görülmektedir.

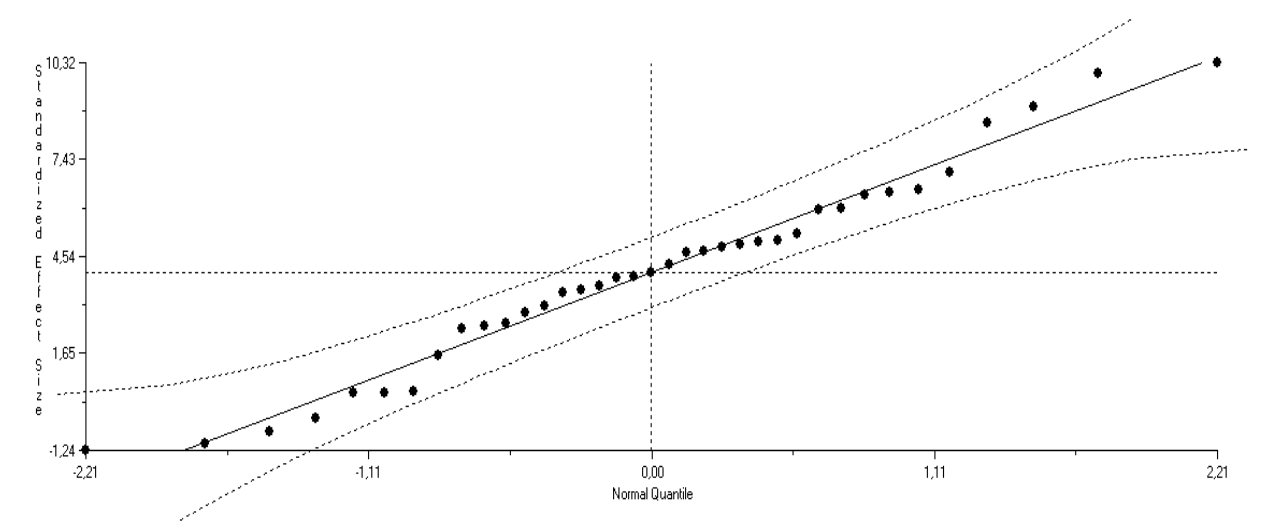

Şekil 1: Normal Quantile Plot

Şekil 1'e bakıldığında noktaların çizdiği aralığın istatistiksel dağılım aralığı olduğu bilinmelidir. Ayrıca iki çizgi arasında yer alan siyah ve belirgin noktaların (analiz dâhilinde her bir çalışmayı temsil etmektedir) dağılım çizgileri arasında olması, dışa taşmaması dağılımın güvenilir aralıkta olduğu şeklinde yorumlanmaktadır (Rosenberg, Adams, ve Gurevitch, 2000). Bu yorum aynı zamanda çalışmalar arasında istatistiksel anlamda ilişki olduğunu göstermektedir. Diğer yandan meta-analiz çalışmalarında yayım yanlılı̆̆ bahsedilmektedir. Genellikle istatistiksel anlamlılık içeren çalışmaların dergiler tarafından yayıma kabul edilmesi ve diğerlerinin yayımlanamadığ araştırmalara dâhil edilmemesi yayım yanlılığı durumunu ortaya çıkarmaktadır. Yayım yanlılığı ise belirli bir konudaki anlamlılığın oldukça yüksek düzeyde çıkmasına yol açmaktadır (Rosenberg, 2005, 464; Scargle, 2000, 91). Bu bağlamda Rosenthal (1979) araştırma yapılan ilgili konuda etki büyüklüğü düzeyini sıfıra çıkaracak kadar çalışmanın daha analiz kapsamına alınması gerektiğini belirtmiştir. Ayrıca meta-analitik değerlendirmelerde, bu ihtimalin belirlenmesi ve gerçekleşmesinin önüne geçilmesi amacıyla farklı metotlar önerilmiştir (Begg ve Berlin 1988; Orwin, 1983). Bu metotlardan en yaygın ve pratik olanı hata koruma sayısının (Fail-safe number/ $F-\mathrm{S}_{\mathrm{N}}$ ) hesaplanmasıdır. Bu sayı ile istatistiksel açıdan 
çok yüksek çıkan anlamlılık düzeyinin azaltılması amaçlanmaktadır. Dolayısıyla bu sayı meta-analize dâhil edilmesi beklenen ve anlamlı farklılık içermeyen ve/ya yayımlanmamış çalışmaları içermektedir. Hesaplanan $F-S_{\mathrm{N}}$ sayısı gözlenen çalışmaların sayısına göre büyük ise araştırma sonuçlarına oldukça güvenilebilir (Rosenberg, 2005, 464). Mevcut araştırmada Metawin programıla hesaplanan F$\mathrm{S}_{\mathrm{N}}$ değeri $8335.7^{\prime}$ dir. 20 çalışmanın analize dâhil edildiği dikkate alındığında, hesaplanan değerin çok büyük olduğu ve sonuçların güvenilir düzeyde olduğu belirtilebilir.

\section{Deneysel Araştırma Bulguları}

Mevcut çalışmada meta-analitik incelemeler yapıldıktan sonra farklı uygulamalar kapsamında birçok yaklaşımın akademik başarıya etkisini inceleyen çalışmalara ulaşılmıştır. Ancak akıllı telefonların akademik başarıya etkisi noktasına alanyazında ulaşılan pek fazla çalışma olmadığı görülmüştür. Dolayısıyla akıllı telefonlar kullanılarak fen bilgisi öğretmen adayları ile işlenen derslerin akademik başarıya olan etkisi ortaya çıkarılmıştır. Bu bağlamda yürütülen zayıf desenlerden biri olan tek grup öntest-sonteste ilişkin veriler Tablo 3'te sunulmuştur.

Tablo 3: Akademik Başarı Tek Grup Öntest-Sontest Puanları

\begin{tabular}{|c|c|c|c|c|c|c|c|c|c|}
\hline \multirow{2}{*}{$\begin{array}{c}\text { Grupla } \\
\mathbf{r}\end{array}$} & \multirow{2}{*}{$\mathbf{n}$} & \multirow{2}{*}{$\overline{\mathbf{X}}$} & \multirow{2}{*}{ ss } & \multirow{2}{*}{ sd } & \multicolumn{2}{|c|}{ Levene } & \multirow{2}{*}{$\mathbf{t}$} & \multirow{2}{*}{$\mathbf{p}$} & \multirow{2}{*}{ EB } \\
\hline & & & & & $\mathbf{F}$ & $\bar{p}$ & & & \\
\hline Öntest & 35 & 15.51 & 2.03 & & & & & & \\
\hline Sontest & 35 & 19.14 & 2.31 & 68 & .305 & $\begin{array}{c}.58 \\
2\end{array}$ & -6.964 & $\begin{array}{c}.00 \\
0\end{array}$ & 1.6509 \\
\hline
\end{tabular}

$* \mathrm{p}<0.05 \quad$ EB

Tablo 3 incelendiğinde çalışma grubunun başarı testi ön ve sontest puanları arasında istatistiksel açıdan anlamlı farklılık tespit edilmiștir. İki testin ortalamaları arasındaki farkın 3.63 düzeyinde olduğu görülmüştür $\left(\overline{\mathrm{X}}_{\text {son }}=19.14 ; \overline{\mathrm{X}}_{\text {ön }}=15.51\right)$. Anlamlı farklılık için $t$ ve $p$ değerleri incelendiğinde, puanların $t$ değerinin $(t=-$ 
6.964, $\mathrm{p}<.05$ ) olduğu görülmektedir. $\mathrm{Bu}$ bulgu, akıllı telefon kullanılan uygulamaların, öğretmen adaylarının akademik başarı sontest puanları üzerinde anlamlı bir etki gösterdiği şeklinde yorumlanabilir. Bu yorum ile akıllı telefon kullanımının akademik başarıyı pozitif yönde etkilediği anlamına gelmektedir. Diğer taraftan deneysel çalışmaya ilişkin hesaplanan etki büyüklüğü değerinin Tablo 3'e bakıldığında ES=1.650 olduğu görülmektedir. Bu değer, Cohen'in (1992) sınıflamasına göre geniş düzeyde bulunmaktadır. Bu veriye göre de akıllı telefonların başarıya etkisi oldukça büyük, anlamlı ve pozitif yöndedir.

\section{Nitel Boyutta Katılımcı Görüşserine İlişkin Bulgular}

Araştırmanın nicel boyuttaki (meta-analiz ve deneysel) bulgularını destekleyici ve tamamlayıcı amaçlı yürütülen nitel boyutta fen bilgisi öğretmen adaylarının görüşleri açısından akıllı telefon uygulamalarının akademik başarı üzerindeki etkililiği sorgulanmıştır. Maxqda analiziyle incelenen görüşler modeller şeklinde Şekil 2 ve Şekil 3’te yansıtılmıştır. İlgili görüşlerin tema ve kodlar biçiminde oluşturulmasının ardından, bu bölümde kodlar metin içinde verilmiş ve ilgili kodların alıntılandığı katılımcılara ait ifadeler doğrudan alıntılar şeklinde ayrıca sunulmuştur. 


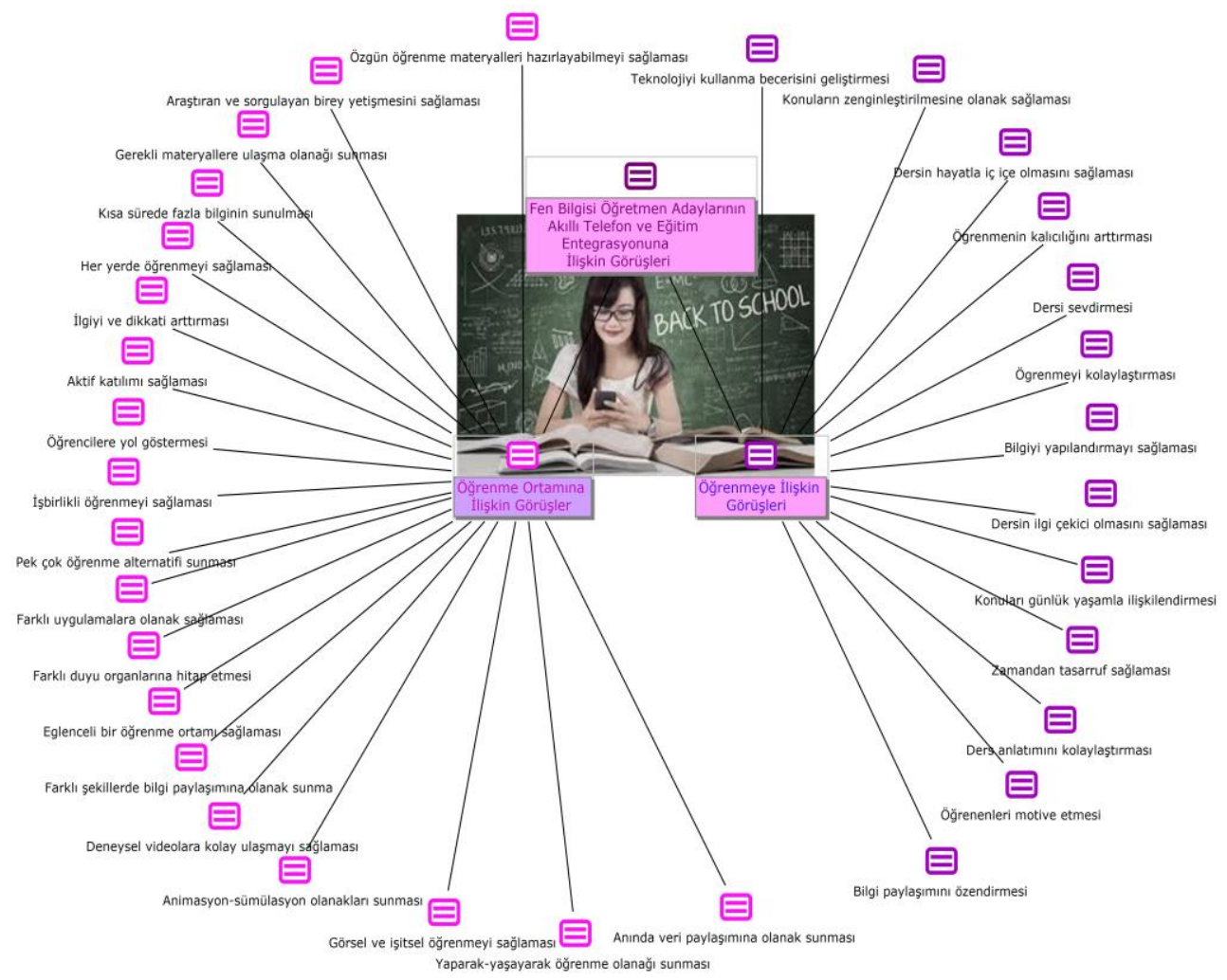

Şekil 2: Akıllı Telefon ve Eğitime Entegrasyonuna İlişkin Görüşler

Şekil 2'de, akıllı telefon ve eğitime entegrasyonu noktasında dile getirilen görüşlerin "öğrenme ortamına ilişkin görüşler" ve "öğrenmeye ilişkin görüşler" olarak iki tema kapsamında gruplaştırıldığı görülmektedir.

Öğrenme ortamı teması bağlamında akıllı telefonların başarıya etkisine ilişkin katılımcılar tarafindan dile getirilen görüşlerden göze çarpan kodlardan bazıları "her yerde öğrenme sağlaması", "farklı şekillerde bilgi paylaşılmasını sağlaması", "animasyon-simülasyon olanakları sunması", "anında veri paylaşımına olanak sunması", "özgün öğrenme materyalleri hazırlamayı sağlaması”, "eğlenceli bir öğrenme ortamı sağlaması" şeklinde belirtilebilir. İlgili kodların alındığı referans cümlelerinden biri K-12 kodlu kat1lımcinın "Akıllı telefonların eğitim sisteminde kullanılması işimizi çok kolaylaştırdı. Artık sınıf ortamı dışında da 
sürekli araştırma ya da sorgulama yapabilme imkânı var. Her an ve her yerde merak ettiğim konulara cevap bulabiliyorum. Bu şekilde öğrenme ilgimi daha çok çekerek hem daha eğlenceli oluyor hem de daha klsa sürede ve pratik şekilde bilgiyi edinebiliyorum..."; diğeri ise E-17 kodlu katılımcının "Telefonun aktif bir şekilde hayatımızda yer alması bu cihazın eğitim anlamında kullanılmasında bizim maksimum düzeyde faydalanmamızı sağlamaktadır. Yani video, animasyon, resim, müzik gibi birçok yöntemle duyuya hitap eden bir mobil bir cihazın etkililik düzeyini maksimumlarda görüyorum. Arkadaşlarla derste işlenenleri video, ses kaydı veya belgenin fotoğrafinı çekerek anında paylaşma imkânı sunmaktadır. Alternatif öğrenme yolları sunan akill telefonların biz ögrencilere gereken materyallere ulaştırmada kolaylık sağladı̆̆ da ayrı bir avantajdır." biçimindeki ifadesidir. Şekil 2'deki kodlar ve ilgili katılımcı alıntıları incelendiğinde, akıllı telefonların eğitimde rol almaya başlamasının, öğrenciler açısından son derece faydalı görüldüğü anlaşılmaktadır.

Diğer yandan Şekil 2'de yer alan akıllı telefonların öğrenmeye yönelik etkisi teması altında farklı birçok kodun bulunduğu görülmektedir. Bu kodlardan bazıları akıllı telefonların "teknolojiyi kullanma becerisini geliştirmesi", “öğrenmenin kalıcılığını arttırması”, dersi sevdirmesi”, "konuların günlük yaşamla ilişkilendirilmesi”, “ zamandan tasarruf sağlaması", "bilgiyi yapılandırmayı sağlaması", "konuların zenginleştirilmesine olanak sağlaması" biçiminde ifade edilebilir. Bu kodların oluşturulmasında kaynak alınan ifadelerden bazıları "akıllı telefonlardan dersimizde yararlanırken ögrendiklerimi çok daha rahat hatırlayabildiğimi fark ettim. Öğrendiklerimin kahıcılığına etki eden akıllı tahta kullanımı görsel ve işitsel özellikler içermesi nedeniyle derste daha çok ilgi uyandirmaktadır.” (E-21); “...işlediğimiz fen konuları bazen çok soyut olabiliyor. Yani bazı kavramların gerçek hayattaki durumu veya daha somut örneği bazen konuyu daha çok kavramayı sağllyor. Bu noktada akıllı telefonların sağladiğı imkânlar dolayısıyla tüm soyut kavramlar bir şekilde somut olarak karşıma çıklyor ve aklımdaki sorulara cevap bulabiliyorum." (K-8); "Akıllı telefonun mobil özelliğ sayesinde her an bilginin yanımızda olması zamandan tasarruf sağlamaktadır. Aksi halde, bilgisayara ulaşmak, bağlantı sağlamak ve o ăğrlıkta bir cihazı sürekli yanımda taşımak gerekir. Oysa hiç bunlara gerek kalmadan sürekli cebimde 
taşılı̆̆ım telefonumla her an bilgiye ulaşmam çok daha kolay oluyor." (K-25) şeklinde ifade edilebilir.

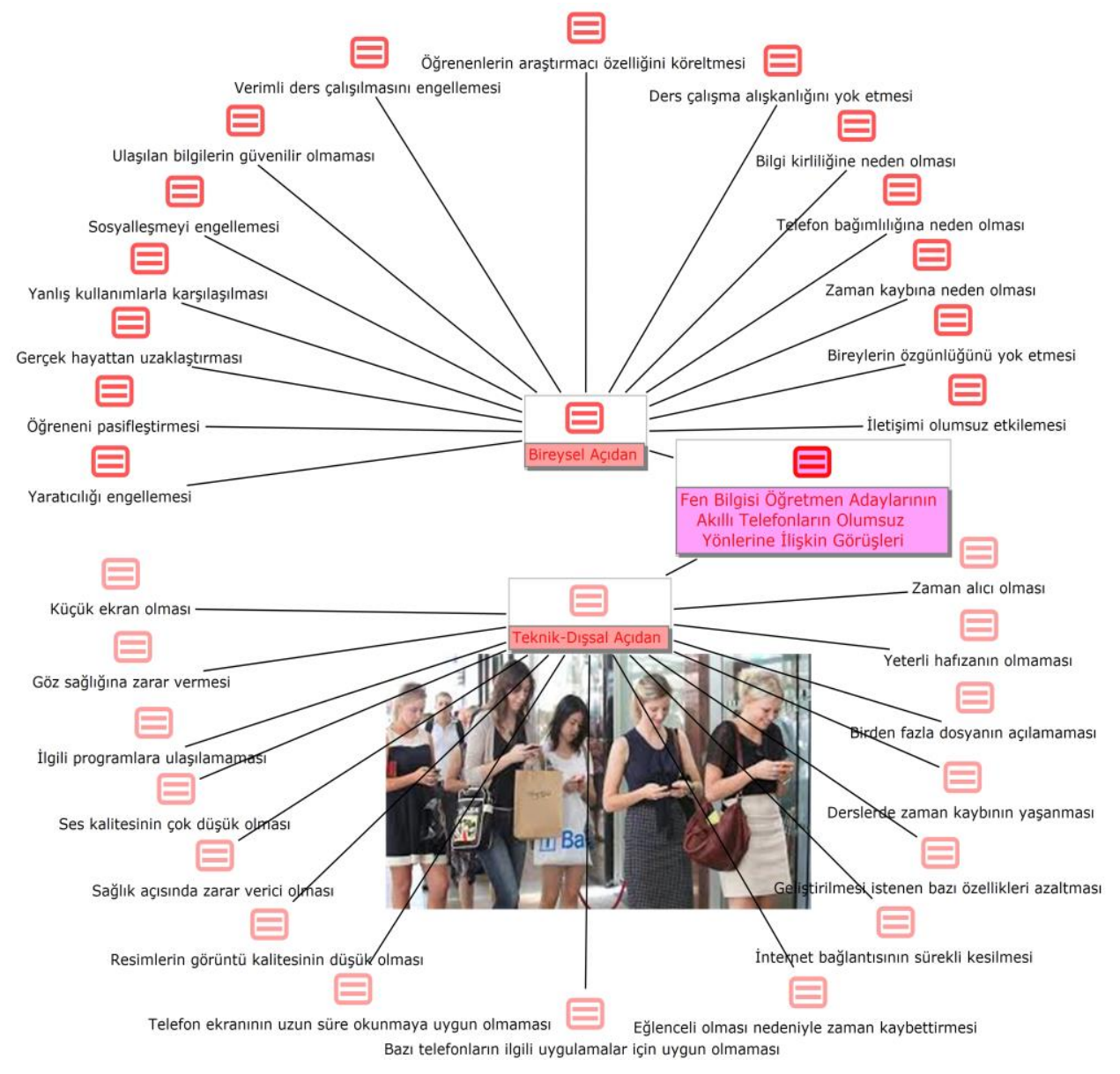

Şekil 3: Akıllı Telefonların Bireysel ve Teknik-Dışsal Açıdan Olumsuz Yönlerine İlişkin Görüşler

Ak1llı telefonların katılımcılar tarafından belirtilen olumlu yöndeki özelliklerinin yanı sıra olumsuz yönleri de bulunmaktadır. Şekil 3'te akıllı telefonların "bireysel” ve "teknik-dışsal” açıdan olumsuz yönlerine değinen kodlar 
sunulmuştur. $\mathrm{Bu}$ bağlamda "bireysel açıdan" dile getirilen olumsuzluklar "öğrenenlerin araştırmacı özelliğini köreltmesi”, "ders çalışma alışkanlığını yok etmesi", "iletişimi olumsuz etkilemesi”, "yaratıcılığı engellemesi”, "zaman kaybına neden olması", "yanlış kullanımlarla karşılaşılması", "bilgi kirliliğine neden olması" şeklinde belirtilebilir.

$\mathrm{Bu}$ kodların oluşturulmasında dayanak alınan katılımcı görüşlerinden bazıları E-33 tarafindan "Akıllı telefonların olumlu özellikleri küçümsenmez derecede çoktur. Ancak bana göre akıllı telefonla araştırma yapmak yerine hazıra konan ögrenciler araştırma becerilerini kaybediyorlar. Sürekli hazır bilgiye ulaşarak sorgulama, inceleme, detaylı arama gibi özellikler noktasında geri kallyorlar. Ayrica sürekli elinde telefon olan arkadaşlarımın sosyal anlamda geri planda olduğunu düşünüyorum. Sanal arkadaşlıklar ve neredeyse sanal bir yaşam tarzına dönüşen bu durumun gerçek yaşama olumsuz etkileri de yok denmeyecek kadardir." şeklinde belirtilirken; K-10 tarafindan "Akullı telefonla herhangi bir konuda rahatça araştırma yapabiliyorum. Ancak ekrana gelen bazı reklamlar ve dikkat dağıtıcı veya konu dışı birtakım ara sayfalar asıl konudan uzaklaşarak bana zaman kaybettirebiliyor. Örneğin bir şarklya, filme veya paylaşım sitelerindeki bir sohbete dalarak asıl inceleme yapmam gereken konu için çok daha az zaman ayırmış olabiliyorum. Bu durum ise telefonu yanlış kullanma ve vakit kaybı gibi olumsuzluklara neden oluyor." şeklinde ifade edilmiştir.

Teknik-dısssal açıdan akıllı telefonların sahip olduğu sınırlılıklar ise "yeterli hafızanın olmaması, "internet bağlantısının sürekli kesilmesi”, "küçük ekran olması", "birden fazla dosyanın açılamaması", "ses kalitesinin çok düşük olması", "göz sağlığına zarar vermesi” biçimindeki kodlarla ifade edilmiştir. Bu kodların alındığ katılımcı görüşlerinden bazıları K-28 kodlu katılımcının "telefon ekranlarının kü̧̈ük olması özellikle göz sağlı̆̆ açısından olumsuz etki oluşturmaktadır. Ayrıca resmin veya görüntünün kaliteli veya tam boyutlu olmasında netlik ve kalite çok yüksek olmuyor." şeklindeki ifadesi, E-2 kodlu katılımcının "Farklı araştırmalar yapma veya birden fazla sayfa açılması telefonun donmasına neden olabiliyor. Dosya indirme durumunda belleğin çok büyük olmaması slkıntılar yaratabiliyor. Bu nedenle çok etkili olmasa da acil durumlarda veya pratik olmak gerektiğinde yine de çok yararlı bir cihaz olarak sürekli hayatımızda." biçimindeki ifadesi ve E-10 kodlu kat1lımcının "Sunum esnasında 
internet bağlantısında sorunlar çıkması olumsuz durumların oluşmasına neden olabiliyor. Sizin bağlantının gelmesini beklemeniz sınıfta dikkatin dağılmasına ve konunun net anlaşılmamasına sebep olabiliyor. Ancak güçlü bir ăg ile bu problemlerle karşılaşılması çok mümkün olmayabilir. Fakat telefonda dersin sunumunun yapılması oldukça büyük bir kolaylık benim açımdan." şeklindeki cümlesidir.

\section{Sonuç ve Tartışma}

$\mathrm{Bu}$ araştırmada farklı uygulamalar ile akıllı telefon kullanımının akademik başarıya etkisinin ne düzeyde olduğu araştırılmıştır. İlgili araştırma üç boyutlu yürütülmüş olup ilk aşamada meta-analiz yapılarak alanyazında farklı uygulamaların akademik başarıya etkisinin genel etki büyüklüğü değerinin ES=1.189 olduğu anlaşılmıştır. Bu değerin Cohen'e (1992) göre geniş düzeyde olduğu söylenebilir. Dolayısıyla farklı uygulamalar kapsamında yürütülen 20 çalışma sonucunda bu uygulamaların akademik başarıyı olumlu yönde etkilediği belirtilebilir. Diğer yandan meta-analiz incelemesinde farklı uygulamaların ayrı ayrı değerlendirilmesi ile ulaşılan etki büyüklükleri Bilgisayar destekli öğretim $\left(E S_{\text {BiLG. }}=1.195\right)$, İşbirlikli Öğrenme Yöntemi $\left(E_{\text {IÖY }}=0.794\right)$, Probleme Dayalı Öğrenme $\quad\left(E_{\mathrm{PDÖ}}=1.666\right), \quad$ "Tahmin Et-Gözle-Açılla” $\quad\left(\mathrm{ES}_{\mathrm{TGA}}=1.273\right)$ ve Yapılandırmacılık (ES $\left.\mathrm{SAP}_{\mathrm{YA}}=1.022\right)$ şeklindedir. İlgili değerlerden İÖY dışındakilerin geniş etki büyüklügü, İÖY'ün ise orta düzeyde etki büyüklügüne sahip olduğu görülmüştür. Bu sonuçlar farklı uygulamalar kapsamında belirtilen yaklaşımların akademik başarıyı olumlu ve anlamlı düzeyde etkilediği şeklinde yorumlanabilir. Ayrıca araştırmada meta-analiz çalışmalarının güvenirliğini sağlamaya yönelik hesaplanan F-SN değerinin 8335.7 olması hesaplanan değerin çok büyük olduğu ve sonuçların güvenilir düzeyde olduğu anlamına gelmektedir. Meta-analitik boyutta dâhil edilen çalışmaların etki büyüklügünün normal dağılıma uygunluğunun sorgulanması amaciyla oluşturulan Normal-quantile plot çizelgesinde ise dağılımın iki çizgi arasında seyrettiği ve bunun normal dağılım ve güvenilir bir sonuç olduğu belirtilebilir.

Günlük yaşantının ayrılmaz bir parçası haline gelen akıllı telefonların öğretim sürecine olan entegrasyonu, bilginin paylaşımına olanak sağlayarak 
öğrenenlerin etkileşimine imkân vermektedir. Çalışmada akı1llı telefon uygulamaları ile desteklenen öğrenme ortamlarının; "her yerde öğrenme sağlaması", "eğlenceli bir öğrenme ortamı sunması", "farklı şekillerde bilgi paylaşılmasına imkan vermesi”, "özgün öğrenme materyalleri hazırlamayı sağlaması", "animasyon-simülasyon ve anında veri paylaşımına olanak sunması" gibi özellikleri nedeniyle geleneksel öğretim metotlarına bir alternatif olarak öğrenme sürecindeki yerini alacağı bulgulanmıştır. İçinde yer aldığımız çevrenin tamamlayıcı bir parçası haline gelen internet, cep telefonları, bilgisayar oyunları ve sosyal ağlara katılımın günümüz öğrenenlerinin düşünme, öğrenme ve bilgiyi işleme şeklinin önceki nesillere oranla büyük ölçüde farklılık göstermesine neden olduğu görülmektedir. İnternet tabanlı öğrenmenin geleceğin öğrenme formu olduğu ve gelecekte öğrenme sistemlerinin sosyal öğeleri bünyesine katacağı düşünülmektedir (Mason ve Rennie, 2008; Wilkins, 2009). Bu kapsamda araştırmada deneysel uygulama yapılması, meta-analiz sonucunda akıllı telefon uygulamalarına ilişkin pek fazla çalışmaya ulaşılmaması sonucunda kararlaştırılmıştır. Yapılan tek grup öntest-sontest deseni sonucunda sontest puanının öntest puanında daha yüksek olması $\left(\bar{X}_{\text {son }}=19.14 ; \quad \bar{X}_{\text {on }}=15.51\right)$ ve anlamlılık içermesi akıllı telefonların akademik başarıyı anlamlı düzeyde etkilediği şeklinde yorumlanabilir. Çalışmada elde edilen bulgular Mason ve Rennie (2008) ile (Wilkins, 2009)'in düşüncelerine paralel niteliktedir. Ayrıca telefonların İngilizce kelime öğrenme konusunda fayda sağladığı ve bu noktada öğrenenlerin öğrenme düzeyine katkı sağladığını belirten bir tez çalışması (Başoğlu, 2010) ile akıllı telefonların öğrenenlerin İngilizce kendini ifade etme becerilerini olumlu yönde etkilediği bulgusuna ulaşan bir çalışmadaki (Seo ve Choi, 2014) sonuçlar mevcut araştırma sonucuyla tutarlı1ık göstermektedir. Ancak bazı araştırmalarda ise akıllı telefon kullanımının bireylerin çalışma zamanlarını kısıtladığı, oyun ve eğlenceli içeriğin daha çok ilgi çekerek ders konusundaki dikkat ve ilgiyi azalttı̆̆ 1 (Lepp, Barkley ve Karpinski, 2015), ödev yapmaktan alıkoyduğu, dilbilgisi ve yazım kurallarına sebep olduğu (Yeboah ve Ewur, 2014) belirtilmiştir.

Araştırmaya nitel boyut eklenmesiyle meta-analiz ve deneysel sonuçlarının güvenirliklerine ve geçerliğine katkıda bulunulmuştur. Nitekim araştırmanın kapsamı genişletilerek araştırmayı destekleyecek bulgu ve sonuçlar eklenmiştir. $\mathrm{Bu}$ bağlamda fen bilgisi öğretmenlerinden alınan görüşler doğrultusunda akıllı 
telefonların öğrenme ortamına ve öğrenmeye etkisi ile bireysel ve teknik-dışsal açıdan karşılaşılan olumsuzluklara ilişkin bulgular elde edilmiştir. Akıllı telefonların her yerde öğrenme imkânı sağlaması, animasyon-simülasyon imkanları sunarak ortamı farklılaştırması, anında paylaşım yapma olanağı sunması gibi özellikler sayesinde öğrenme ortamını etkili kıldığı anlaşılmıştır. Ayrıca içerdiği uygulamalar sayesinde öğrenme açısından da eğlenceli etkinlikler sağladığı, konuların öğrenilmesini zevkli kıldığı görülmüştür. Katılımcıların görüşlerine göre akıllı telefonlarla bilginin kalıcı öğrenildiği, konu öğretiminde zengin materyalle karşılaşıldığı, çabukluk ve pratiklik kazandırıldığı şeklindeki bulgular akıllı telefonların eğitime entegrasyonunda öğrenme eyleminin oldukça olumlu yönde etkilendiği anlamına gelmektedir.

Ancak her uygulamada bazı sinırlılıklarla karşılaşıldığ gibi akıllı telefon uygulamalarının kullanımında da birtakım sorunlar yaşanabilmektedir. Araştırma bağlamında katılımcıların ifade ettikleri sınırlılıklar iki başlık altında incelenmiştir. İlk olarak akıllı telefonların bireysel açıdan içerdiği olumsuzluklara değinilmiştir. Yaratıc1lığı engellemesi, sosyal çevreden uzaklaştırması, bağımlılığa neden olması, bireyi pasif ve etkisiz hale getirmesi bu bağlamda dile getirilen bazı görüşlerdir. Yapılan birçok araştırmada da telefonların benzer nitelikteki sonuçlara ulaşıldığı görülmüştür (Kibona ve Rugina, 2015; Lee, Chang, Lin ve Cheng, 2014). Bunun yanı sıra teknik açıdan da bazı olumsuzlarla karşılaşıldığı bilinmektedir. Akıllı telefonların ekran boyutunun ve ses kalitesinin görme ve duyma açısından sağlığa zarar vermesi, hafıza sınırlılığı, internet bağlantısı gerekliliği, şarj durumu gibi sınırlılıklar da istenmeyen durumlar oluşturabilmektedir.

Araştırma sonuçları genel çerçevede incelendiğinde, akıllı telefon uygulamalarının öğretimde rol almaya başlamasının, öğretmen adayları açısından son derece faydalı bulunduğu anlaşılmaktadır. Katılımcı görüşleri doğrultusunda ulaşılan bulgular sonucunda, akı1lı telefon uygulamalarının öğretim sürecini olumlu anlamda desteklediği anlaşılmıştır. Bu doğrultuda öğrenme ortamlarının internet tabanlı telefon uygulamaları ile desteklenmesinin kalıcı ve anlamlı bir öğrenmeye katkı sağlayacağı düşünülmektedir. İnternet tabanlı uygulamaların yaygın kullanım oranı ve bünyesinde barındırdığı iletişim, etkileşim ve işbirliği araçları sayesinde pek çok farklı öğrenme düzeyine hizmet edebilme potansiyeline sahip olduğu görülmektedir (Thomson, 2003). Öğrenenlere sınıf içi deneyimlerini 
paylaşabilecekleri uygun bir ortam hazırlaması, sosyal destek ve işbirliğini arttırması, daha esnek bir öğrenme ortamı sunması, öğretim ve değerlendirme süreçlerinde daha farklı uygulamalara firsat vermesi, araştırma sürecini desteklemesi, bilgileri gönderme, düzeltme ve paylaşma imkânı sağlaması, yaşam ve okul arasında iletişim dinamiklerini gerçekleştirme potansiyeline sahip olması internet tabanlı uygulamaların öğrenme ortamlarında daha çok tercih edilmesine yol açmaktadır (Atıcı ve Yıldırım, 2010; Blackey ve Chew; 2009).

Gelecek nesiller, günümüz teknolojisinin var olduğu ortamda doğmuş ve bilgisayar, cep telefonları ve internet gibi teknolojiler ile büyümüş ana dilini öğrenir gibi teknoloji öğrenmiş kişilerden oluşacaktır. Teknolojiyi bir dil gibi kullanabilen, zihinlerini teknoloji diliyle işleten bu neslin eğitimini; teknolojiye yeterince hâkim öğretmenlerden ve eğitim yöneticilerinden oluşan bir kadro verebilecektir (Prensky, 2001). Bu bağlamda, günümüzde teknolojinin gelişimi ve öğretim ortamlarında kullanımı ön plana çıkmakta ve öğretmen yetiştirme süreçlerinin de bu bağlamda ele alınması bir zorunluluk halini almaktadır. Bu nedenle; teknoloji okuryazarlığı yüksek, öğrenme çevrelerini sosyal ağlar ile zenginleştirebilen ve internet tabanlı uygulamaları ögrenme sürecinde kullanabilme becerisine sahip öğretmen adaylarının yetiştirilmesi önem kazanmaktadır. Öğretmen yetiştirme sistemi içerisinde sosyal ağların etkin kullanımına ilişkin gerekli teknik alt yapıların sağlanması öğretmen adaylarının güncel teknolojilerin kullanımına yönelik becerilerinin gelişimine katkıda bulunacaktır. Öğretmen yetiştirme programları, öğretmen adaylarının pedagoji ve içerik bilgilerine dayalı olarak teknoloji kullanımlarını sağlayacak derslerle desteklenebilir. $\mathrm{Bu}$ tür uygulamalı ortamlarda bilgi ve becerileri geliştirici yönde alınan eğitimler, öğretmen adaylarının teknoloji kullanım bilgilerinin paralelinde teknopedagojik eğitim yeterliklerinin gelişmesine de katkı sağlayacaktır (Yurdakul, 2011). Sonuç olarak akıllı telefonların eğitimle entegrasyonunda öğrenmeye katkısının küçümsenemez düzeyde olduğu görülerek uygulamanın kullanımı esnasında karşılaşılması muhtemel olumsuzlukların ortadan kaldırılması amaçlanmalıdır. Bunun için akıllı telefonun kullanımında öncelikli olarak kullanılacak kademedeki program, içerik, sınıfın donanımsal durumu dikkate alınmalı ve bu boyutlardaki uyumu sağlanmalıdır. Ayrıca akıllı telefon kullanımının tutum boyutuna etkisinin ne düzeyde olduğu farklı araştırmalarla incelenebilir. 


\section{Extended Summary}

Science can be defined as a systematic study of nature and natural phenomena, and efforts to reduce unscheduled events. The content of the science covers concepts, principles and generalizations, theories and laws of nature (Kaptan and Korkmaz, 2001). In order for teachers to effectively transfer science to learners, the process of teacher training needs to be considered in a comprehensive way. In this context, science teacher candidate (Meriç and Tezcan, 2016) should be the ones who have high academic achievement; have knowledge of the field; follow interdisciplinary relations very well and research, examine and teach critical thinking; develop students' internal stimuli.

There are a number of studies aimed at increasing the "academic achievement", which is one of the main factors in the process of training science teacher candidates (Yip, 2001; Alouf and Bentley, 2003; Kageey, 2004; Kearney, 2004; Burke, Hand, Poock and Greenbowe, 2005; Hohenshell and Hand, 2006; Wise and Bluhm, 2008; Gardner, 2008). In these studies; "problem-based learning, computer-supported education, context based approach, laboratory applications based on guess-observe-explain method, research based learning, concept maps, internet based phone applications, Science Writing Heuristic Approach, portfolio application, multiple intelligence theory, project based learning, 5E learning model based on laboratory applications can be stated as the main methods and techniques. It is understood from the related research results that these applications which help teaching contents to be presented in different forms positively contribute to academic success and knowledge permanence that it helps to improve scientific process and problem solving skills and affects the attitude towards the course positively.

The current study aims to show how effective different teaching methods and techniques are in academic achievement. In this scope; researches in which different teaching methods and techniques are used in the teaching environment are examined by taking into consideration certain criteria and it is aimed to present a qualified study in this direction. Within the scope of meta-analysis; it is thought that more comprehensive and general conclusions about candidates' academic achievement can be achieved. There are a number of studies examining the impact 
of social networks on learning, focusing on how social media can be used in the teaching process, including educational analysis of individual activities in social networks related to the use of technology when the related literature is searched (Selwyn, 2009; Kwon and Wen, 2010; Ekici and Kıy1c1, 2012) However, studies regarding the impact of smartphone applications based on internet on academic achievement are limited (Murray, 2008, Hung and Yuen, 2010, Junco, 2012; Öztürk and Tetik, 2015). There are different studies in the related literature rather than the present technology-focused research. In this context, it can be stated that smartphones contribute to filling the gap in the area, that this research is expected to share the results of its use in education, and that the results of relevant research are expected to shed light on future studies.

In this study, a meta-analysis, an experimental application and a thematic analysis were applied to assess the effectiveness of some teaching approaches, which we have characterized as different applications, in the science achievement context. The purpose of this work, which is carried out both quantitatively and qualitatively, is to achieve more general conclusions and judgments by obtaining more comprehensive and broader data. For inclusion criteria studies which were conducted between 2008 and 2017; that including the statistical values such as sample size (n), arithmetic mean (X) and standard deviation (ss) to achieve the effect size value; that using the pre-test and post-test control group model were selected. As a result, 20 studies that meet these criteria were included in the study. Data obtained in the context of meta-analysis were analyzed by CMA and MetaWin programs and Cohen's (2002) level classification was taken into account in interpretations.

In order to investigate the effect of smartphone usage on academic achievement, smartphone application was performed in the lessons that were processed with Science teacher candidates. In the academic year of 2016 and 2017, 35 science teacher candidates selected from 3rd graders of Kilis 7 Aralık University Department of Science Teacher Training formed the study group. Academic achievement test was prepared in order to reach the pretest and posttest data by applying it before and after the application. The mean difficulty was calculated to be .571 while the KR-20 reliability factor of the test was .91 whose reliability was provided by the TAP program. Analysis of the data was performed 
by SPSS-18 program. Finally, a qualitative view was applied to support the results of the meta-analysis and experimental application of the research. In this study, which was carried out according to the action research design, the data were analyzed with the Maxqda-11 program and Cohen Kappa agreement values were calculated (Viera and Garrett, 2005).

According to the findings of the study, it was understood that the overall effect size of the academic achievement of different applications in the context of meta-analysis is found to be as ES $=1.189$. This value can be said to be large effect according to Cohen (1992). Therefore, these practices can be stated to have a positive effect on academic achievement as a result of 20 studies conducted on different applications. Experimental implementation in the study was the result of meta-analysis resulting in a lack of work on smartphone applications. At the end of the pretest-posttest single-group experimental application, it can be interpreted that the posttest score is higher than the pretest score $\left(\bar{X}_{\text {post }}=19.14, \bar{X}_{\text {pre }}=15.51\right)$ and that there is a meaningful difference. Thus, it can be true to identify that smartphone influences the academic achievement significantly. On the other hand, from the views of science teacher candidates, the effect of smartphones on learning and learning environment and negative aspects of smartphones (individual and technical-external problems) were obtained. Despite the negative effects, it can be recognized that smartphones can provide permanent learning, present rich material, gain quickness and practicality. Therefore, the results suggest that educational integration of smartphones positively affect the learning action.

\section{Kaynakça}

\section{Kitaplar}

Blackey, H. ve Chew, E. (2009). Social Software Policy 2009-2012 for The University of Glamorgan. The Policy of the University of Glamorgan.

Borenstein, M., Hedges, L. V., Higgins, J. P. T. ve Rothstein, H. R. (2009). Introduction to Meta-analysis. West Sussex: Wiley.

Creswell, J. W., Plano Clark, V. L., Gutmann, M. L. ve Hanson, W. E. (2003). Advanced mixed methods research designs. In A. Tashakkori \& C. Teddlie 
(Eds.), Handbook of mixed methods in social and behavioral research (pp. 209-240). Thousand Oaks, CA: Sage.

Gardner, H. E. (2008). Multiple intelligences: New horizons in theory and practice. Basic books.

Kaptan, F. ve Korkmaz, H. (2001). Ilköğretimde Fen Bilgisi Öğretimi: Modül 7, Ankara: MEB.

Mason, R. ve Rennie, F. (2008). Social networking as an educational tool. Elearning and social network handbook: Resources for Higher Education. New York: Routledge.

Patton, M. Q. (2014). Nitel araştırma ve değerlendirme Yöntemleri (M. Bütün ve S. B. Demir, çev.). Ankara: Pegem Akademi.

Rosenberg, M. S., Adams, D. C. ve Gurevitch, J. (2000). MetaWin statistical software for meta-analysis version 2.0, Massachusetts, MA: Sinauer Associates Inc.

Thomson NETg. (2003). Thomson job impact study: The next generation of corporate learning. Naperville, IL: Thomson NETg.

Yıldırım, A. ve Şimşek, H. (2008). Sosyal bilimlerde nitel araştırma yöntemleri, (Genişletilmiş ve Güncelleştirilmiş 6. Baskı), Ankara: Seçkin Yayıncılık.

\section{Tezler}

Başoğlu, E. B. (2010). Cep telefonu ve sözcük kartı kullanan ögrencelerin Ingilizce sözcük öğrenme düzeylerinin karşılaştırması. Yayımlanmamış yüksek lisans tezi, Zonguldak Karaelmas Üniversitesi, Sosyal Bilimler Enstitüsü, Zonguldak.

Günay, H. (2008). Boşaltım sistemi konusunu öğrenmede bilgisayar destekli ögretimin fen bilgisi ögretmen adaylarının başarılart üzerine etkisi. (Yayımlanmamış Yüksek Lisans Tezi). Gazi Üniversitesi, Ankara.

Menevşe, E. B. (2012). Portfolyo uygulamasının ögretmen adaylarının akademik başarılarına etkisi. (Yayımlanmamış Yüksek Lisans Tezi). Necmettin Erbakan Üniversitesi, Konya. 


\section{Makaleler}

Akgöz, S. ve Ercan, İ. ve Kan, İ.(2004). Meta-analizi. Uludağ Üniversitesi Tip Fakültesi Dergisi, 30(2), 107-112.

Alouf, J. L. ve Bentley, M. L. (2003). Assessing the impact of inquiry-based science teaching in professional development activities, PK-12.

Backer, E. (2010). Using Smartphones and Facebook in a major assessment: The student experience. e-Journal of Business Education \& Scholarship of Teaching, 4 (1), 19-31.

Begg, C. B. ve J. A. Berlin. (1988). Publication bias: a problem in interpreting medical data. J. R. Stat. Soc. A 151:419-463.

Burke, K. A., Hand, B., Poock, J. ve Greenbowe, T. (2005). Using the Science Writing Heuristic: Training Chemistry Teaching Assistants. Journal of College Science Teaching, 35(1), 36.

Turpin, T. ve Cage, B. N. (2004). The effects of an integrated, activity-based science curriculum on student achievement, science process skills, and science attitudes. Louisiana Department of Education. Electronic Journal of Literacy through Science, 3, 1-17

Cohen, J. (1992). Statistical power analysis. Current Directions in Psychological Science, 1(3), 98-101.

Ekici, M. ve Kıyıcı, M. (2012). Sosyal ağların eğitim bağlamında kullanımı. Uşak Üniversitesi Sosyal Bilimler Dergisi, 5(2), 156-167.

Glass, G. V. (1976). Primary, secondary, and meta-analysis of research. Educational Researcher, 5(10), 3-8.

Hohenshell, L. M. ve Hand, B. (2006). Writing-to-learn strategies in Secondary School Cell Biology: a mixed method study. International Journal of Scinece Education, 28(2-3), 261-289.

Hung, H. T. ve Yuen, S. C. Y. (2010). Educational use of social networking technology in higher education. Teaching in Higher Education, 15(6), 703714.

İşman, A. ve Albayrak, E. (2014). Sosyal ağlardan Facebook'un eğitime yönelik etkililiği. Trakya Üniversitesi Ĕgitim Fakültesi Dergisi, 4(1). 
Junco, R. (2012). Too much face and not enough books: The relationship between multiple indices of Facebook use and academic performance. Computers in Human Behavior, 28(1), 187-1.

Kearney, M. (2004). Classroom use of multimedia-supported predict-observeexplain tasks in a social constructivist learning environment. Research in Science Education, 34(4), 427-453.

Kibona, L., ve Rugina, J. M. (2010). A Review on the Impact of Smartphones on Academic Performance of Students in Higher Learning Institutions in Tanzania. Journal of Multidisciplinary Engineering Science and Technology (JMEST), 2(4), 673-677.

Klegeris, A., ve Hurren, H. (2011). Impact of problem-based learning in a large classroom setting: student perception and problem-solving skills. Advances in Physiology Education, 35(4), 408-415.

Kwon, O., ve Wen, Y. (2010). An empirical study of the factors affecting social network service use. Computers in Human Behavior, 26(2), 254-263.

Lam, L. (2012). An innovative research on the usage of facebook in the higher education context of Hong Kong. Electronic Journal of E-learning, 10(4), 378-386

LeCompte, M. D. ve Goetz, J. P. (1982). Problems of reliability and validity in ethnographic research. Review of Educational Research, 52(1), 31-60.

Lee, Y. K., Chang, C. T., Lin, Y. ve Cheng, Z. H. (2014). The dark side of smartphone usage: Psychological traits, compulsive behavior and technostress. Computers in Human Behavior, 31, 373-383.

Lepp, A., Barkley, J. E. ve Karpinski, A. C. (2015). The relationship between cell phone use and academic performance in a sample of U.S. college students. SAGE Open, 5(1), 1-9.

Lim, T. (2010). The use of Facebook for online discussions among distance learners. Turkish Online Journal of Distance Education, 11(4), 72-81.

Malita, L. (2011). Can we use Facebook like a teaching and learning tool?. Educa IA-Plus Journal Plus Education, 7(1), 101-109.

Meriç, G. ve Tezcan, R. (2016). Fen bilgisi öğretmeni yetiştirme programlarının örnek ülkeler kapsamında değerlendirilmesi (Türkiye, Japonya, Amerika ve 
İngiltere örnekleri). Ballkesir Üniversitesi Fen Bilimleri Enstitüsü Dergisi, 7(1), 62-82.

Minocha, S. ve Roberts, D. (2008). Social, usability, and pedagogical factors influencing students' learning experiences with wikis and blogs. Pragmatics \& Cognition, 16(2), 272-306.

Murray, C. (2008). Schools and social networking: Fear or education. Synergy Perspectives: Local, 6(1), 8-12.

Orwin, R. G. (1983). A fail-safe $N$ for effect size in meta-analysis. J. Educ. Stat. 8, $157-159$.

Öztürk, Ö. K. ve Tetik, E. (2015). Sosyal ă̆ destekli bilişim teknolojileri eğitiminin öğrencilerin akademik başarılarına etkisi. Education Sciences, 9(7), 151-168.

Prensky, M. (2001). Digital natives, digital immigrants part 1. On the Horizon, 9(5), 1-6.

Rosenberg, M. S. (2005). The file-drawer problem revisited: a general weighted method for calculating fail-safe numbers in meta-analysis. Evolution, 59(2), 464-468.

Sánchez, R.A., Cortijo, V. ve Javed, U. (2014). Students' perceptions of Facebook for academic purposes. Computers \& Education, 70, 138-149.

Scargle, J. D. (2000). Publication bias: the "file-drawer" problem in scientific inference. Journal of Scientific Exploration, 14(1), 91-106.

Schwartz, L., Clark, S., Cossarin, M. ve Rudolph, J. (2004). Educational wikis: Features and selection criteria. The International Review of Research in Open and Distributed Learning, 5(1), 1-6.

Selwyn, N. (2009). Faceworking: exploring students' education-related use of Facebook. Learning, Media and Technology, 34(2), 157-174.

Seo, W. ve Choi, I-C. (2014). The effect of using a smart-phone speaking application on Korean middle school students' English expression learning and satisfaction. Multimedia-Assisted Language Learning, 17(1), 34-57.

Stroup D. F., Berlin, J. A., Morton, S. C., Olkin, I., Williamson, G. D., Rennie, D.,...Thacker, S. B. (2000). Meta-analysis of observational studies in epidemiology: A proposal for reporting. JAMA, 283(15), 2008-2012. 
Viera, A. J. ve Garrett, J. M. (2005). Understanding interobserver agreement: The kappa statistic. Family Medicine, 37(5), 360-363.

Wise, K. ve Bluhm, W. J. (2008). Scientific observation and the learning cycle: burning the candle at both ends. Journal of College Science Teaching, 37(3), 58.

Witte, K. ve Allen, M. (2000). A meta-analysis of fear appeals: 1mplications for effective public health campaigns. Health Education \& Behavior, 27, 591615. DOI: $10.1177 / 109019810002700506$.

Yeboah, J. ve Ewur, G. D. (2014). The impact of whatsapp messanger usage on students performance in tertiary institutions in Ghana. Journal of Education and Practice, 5(6), 157-164.

Yip, D. Y. (2001). Promoting the development of a conceptual change model of science instruction in prospective secondary biology teachers. International Journal of Science Education, 23(7), 755-770.

Yurdakul, I. K. (2011). Öğretmen adaylarının teknopedagojik eğitim yeterliklerinin bilgi ve iletişim teknolojilerini kullanımları açısından incelenmesi. Hacettepe Üniversitesi Eğitim Fakültesi Dergisi, 40, 397-408.

\section{Bildiriler}

Atıcı, B. ve Yıldırım, S. (2010). Web 2.0 uygulamalarının e-öğrenmeye etkisi. Akademik Bilişim, 10, 10-12.

Augar, N., Raitman, R. ve Zhou, W. (2004). Teaching and learning online with wikis. In Beyond the comfort zone: proceedings of the 21st ASCILITE Conference, Perth, 5-8 December (pp. 95-104).

Klangmanee, R., ve Sumranwanich, W. (2009). The development of grade 5 Thai students' metacognitive strategies in learning about force and pressure through Predict Observe Explain (POE). In Third International Conference on Science and Mathematics Education (CoSMEd), Penang, Malaysia.

Kolari, P., Finin, T., ve Joshi, A. (2006). SVMs for the blogosphere: blog 1dentification and splog detection. In AAAI Spring Symposium: Computational Approaches to Analyzing Weblogs (pp. 92-99). 


\section{Web Siteleri}

Rosenthal, R. (1979). The file drawer problem and tolerance for null results. Psychological Bulletin, 86 (3), 638-641. http://dx.doi.org/10.1037/00332909.86.3.638

Wilkins, D. (2009). Learning 2.0 and Workplace Communities. The American Society for Training and Development. Retrieved from http://www.astd.org/lc/2009/0209_wilkins.html. 
EK - A: Tap Analiz Sonuçları

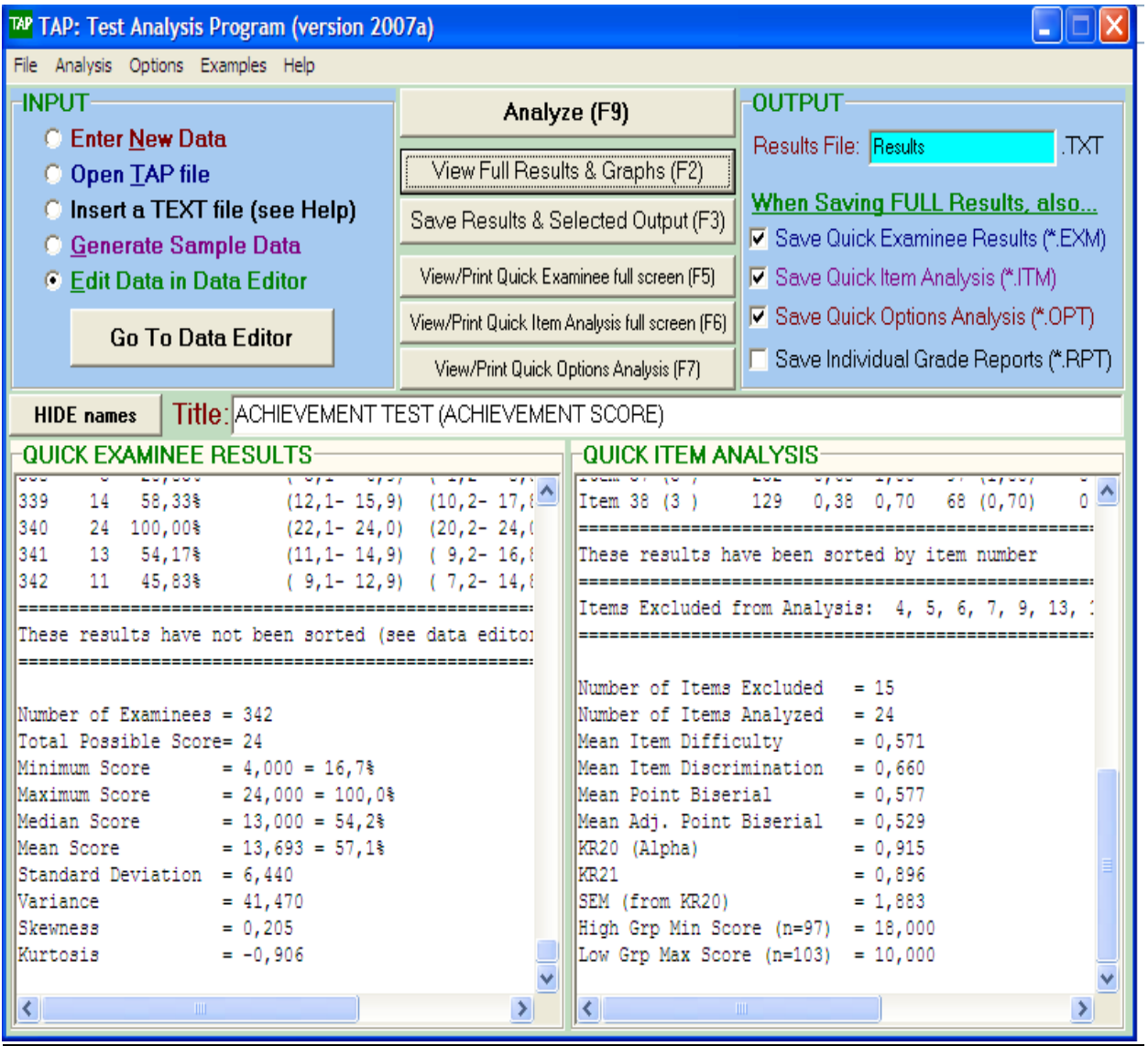

\section{EK - B: Görüssme Formu}

Öğretmen Adaylarının Görüşleri Açısından Akıllı Telefon Uygulamalarının Akademik Başarı Üzerindeki Etkililiğine İlişkin Görüşme Formu

Akıllı telefonların;

1. Öğrenmeye ve öğrenme ortamına etkisine ilişkin görüşlerinizi belirtiniz.

2. Bireysel ve teknik-dışsal açıdan olumsuz yönlerine ilişkin görüşlerinizi yazınız. 